AperTO - Archivio Istituzionale Open Access dell'Università di Torino

\title{
Assessing the Distributional Effects of Housing Taxation in Italy: A Microsimulation Approach
}

\section{This is the author's manuscript}

Original Citation:

Availability:

This version is available http://hdl.handle.net/2318/102332

since 2017-05-16T19:42:11Z

Published version:

DOI:10.1093/cesifo/ifs004

Terms of use:

Open Access

Anyone can freely access the full text of works made available as "Open Access". Works made available under a Creative Commons license can be used according to the terms and conditions of said license. Use of all other works requires consent of the right holder (author or publisher) if not exempted from copyright protection by the applicable law. 


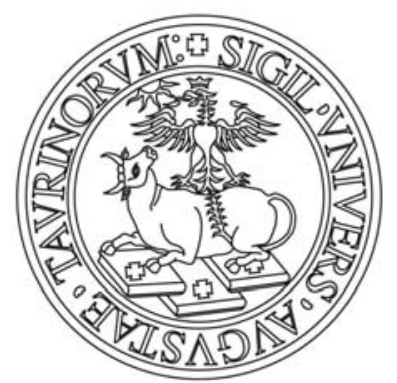

\section{UNIVERSITÀ DEGLI STUDI DI TORINO}

This is an author version of the contribution published on:

Questa è la versione dell'autore dell'opera:

S. Pellegrino, M. Piacenza, G. Turati, "Assessing the Distributional Effects of Housing Taxation in Italy: A Microsimulation Approach", CESifo Economic Studies, vol. 58, n. 3, September 2012, pp. 495-524, Oxford University Press, doi:10.1093/cesifo/ifs004.

The definitive version is available at: La versione definitiva è disponibile alla URL: http://cesifo.oxfordjournals.org/ 


\title{
Assessing the Distributional Effects of Housing Taxation in Italy: A Microsimulation Approach*
}

\author{
Simone Pellegrino ${ }^{\mathrm{a}}$ \\ Massimiliano Piacenza ${ }^{\mathrm{b}}$ \\ Gilberto Turati $^{\mathrm{c}}$
}

\begin{abstract}
The presence of extensive housing subsidies characterises the current Italian tax systems as inefficient. In this paper, we study whether inefficiency is the price to be paid to improve equity, by assessing the distributive impact of housing taxation on households wellbeing. We concentrate on the Personal Income Tax (PIT) on the main residence, and compare current provisions of the Tax Code with alternative approaches, which consider the imputed rent (IR) from owner-occupied dwelling, and would make the tax system neutral with respect to the allocation of wealth among different assets. Holding revenues constant at the current level, we assess the distributional consequences of the IR approach under several alternative scenarios. Our results suggest that the current tax system is just as inefficient as it is inequitable. In particular, by including IR from owner-occupied dwellings as a component of the PIT gross income, we find that overall inequality is reducing, while contemporaneously increasing efficiency in the allocation of wealth. Moreover, considering changes in tax liabilities for individual taxpayers, we show that taxing imputed rents will favour the young and penalise the elderly.
\end{abstract}

JEL Codes: H24, D31

Keywords: Housing taxation, Imputed rent, Personal Income Tax, Microsimulation models

\footnotetext{
* We wish to thank Niku Määttänen and an anonymous referee of this journal for their comments, that helped us improve the paper. We also thank Massimo Baldini, Ruben Cox, Joachim Frick, Carla Marchese, Panu Poutvaara, Kathleen Short, Michael Smart, and all seminar participants to the $31^{\text {st }}$ General IARIW Conference (St. Gallen, 2010), the XXII SIEP Conference (Pavia, 2010), and the CESifo Conference on Housing Taxation and Regulation (Munich, 2010), for useful suggestions on previous drafts of this paper. Usual disclaimers apply.

a University of Torino, School of Economics, Department of Economics and Public Finance “G. Prato”, e-mail: pellegrino@econ.unito.it.

b University of Torino, School of Economics, Department of Economics and Public Finance "G. Prato"; e-mail: piacenza@econ.unito.it.

c Corresponding author: University of Torino, School of Economics, Department of Economics and Public Finance "G. Prato", Corso Unione Sovietica 218 bis, 10134 Torino (TO), Italy; phone: +39.011.670.6046, fax: +39.011.670.6062, e-mail: turati@econ.unito.it.
} 


\section{Introduction}

Homeownership is largely subsidised all around the world with a blend of different measures. Imputed rents are often excluded from the tax base of the Personal Income Tax, while interests paid on mortgages are often deductible. The justifications for these important government interventions are based on both efficiency and equity arguments (e.g., Rosen, 1985; Quigley, 2008). On the efficiency side, it is recognised that there are positive externalities in housing consumption: for instance, improving one's own property has positive effects on property values in the neighbourhood. However, it is doubtful that all investments generate positive externalities: painting interior walls, for instance, is likely to have no spill-over effects on other owner occupiers. Hence, for a number of reasons, housing subsidies are most probably better justified on equity grounds. First, homeownership has a large impact on wellbeing, and the impact is presumably larger for the poor (e.g., Watson et al., 2007). Second, houses constitute a large share of individual wealth portfolios (e.g., Sierminska et al., 2008); again, this share is presumably larger for poor households. Third, homeownership is associated with a variety of collateral positive effects, which are larger for the poor and contribute to reduce social inequalities. A strand of literature suggests for instance that children benefit from home-owning, because they stay in school longer and perform better; and these effects are particularly important for low income households (e.g., Green and White, 1997). Moreover, among the poor, homeowners are less involved in crimes, again contributing to trim down social disparities (e.g., Glaeser and Sacerdote, 1999).

Of course, as homeownership is subsidised, current tax systems are inefficient, and conducive to excess investments in housing with respect to alternative assets, like stocks and bonds (e.g., Sierminska et al., 2008). However, given the significance of equity considerations in justifying housing subsidies, inefficiencies can be the price to be paid in order to foster equity, so that it is important to study the redistributive effects of the current tax systems, as well as to understand who they really target. This is even more true in the presence of a booming housing market (which was experienced in recent decades in almost all countries, despite the latest retrenchment) and sluggish-to-adapt tax systems (with tax bases largely reflecting historical values). 
With respect to these arguments, Italy is an important case study. Homeownership has historically received (and still continue to receive) large tax subsidies. Not surprisingly, the share of owner-occupied dwellings has increased heavily after the II World War, climbing to about 70 percent of households, a number that characterizes Italy as one of the Western countries with the highest share of owner-occupiers (close to the situation of UK, Finland and Norway; e.g., Watson et al., 2007; Bernardi and Poggio, 2004). Moreover, differently from other countries, Italy shares with the Mediterranean countries also a high number of owner-occupiers which is coupled with a particularly generous system of public pensions, generating a substantial redistribution in favour of the elderly (e.g., Ferrera and Castles, 1996). Tax subsidies are even larger now, due to the combination of a sharp increase of prices in the housing market - the average value of the dwelling with respect to household income climbed from 3.5 in 1977 to 5.8 in 2004 - and the fact that tax bases are locked at 'cadastral' values (i.e., imputed rents administratively defined) far from market prices. On the contrary, public expenditures on housing are among the lowest in industrialized countries: a mere 0.1 percent of welfare expenditures compared with an average 3.5 percent in the EU countries (D’Alessio and Gambacorta, 2007). Also fiscal expenditures are substantially lower than other countries, given the scant use of mortgages with respect to other countries (Bernardi and Poggio, 2004; Sierminska et al., 2008).

Starting from these premises, in this paper we aim at assessing the redistributive effects of housing tax system in Italy using a microsimulation model. In particular, we concentrate on the Personal Income Tax on the main residence, and compare the present situation with alternative ones, aimed at making the tax system neutral with respect to investments in alternative assets besides houses, like stocks and bonds ${ }^{1}$. To do so, we consider an 'imputed rent', based on current market prices, as the tax base for housing. In this sense, our work is related to the literature assessing the impact of imputed rents on income distribution (e.g., Bourassa and Hendershott, 1994, and Yates, 1994, for Australia; Yagi and Tachibanaki, 1998, for Japan; Frick and Grabka, 2003, for the UK, the US, and West Germany; D’Ambrosio and Gigliarano, 2007, for Italy; Callan and Keane, 2009, for Ireland; Onrubia et al., 2009, for Spain; Wolff and Zacharias, 2009, for

\footnotetext{
${ }^{1}$ We do not consider here the issue of tenure-neutrality. On this point, see Thalmann (2007).
} 
the US; Frick et al., 2010, for Belgium, Germany, Greece, Italy, and UK). Main results of this literature sum to a somewhat mixed evidence. Moreover, most of these papers do not explicitly consider the role of taxes in influencing income distribution. Here we rely on a static microsimulation model (discussed in Pellegrino et al., 2011), and simulate the Personal Income Tax on the main residence under alternative scenarios, using as input data the Bank of Italy Survey on Household Income and Wealth. Our main results suggest that the current tax system is both inefficient and inequitable. In particular, by including imputed rent from owner-occupied dwellings as a component of the Personal Income Tax base, we find that overall inequality - measured by the Gini coefficient - is reducing. Moreover, considering changes in tax liabilities, we show that taxing imputed rent will favour the young and penalise the elderly.

The remainder of the paper is structured as follows. Section 2 sets the stage, providing essential background information on the housing taxation system in Italy in the context of an optimal taxation scheme for housing. In section 3, we briefly present our microsimulation model and the data. Section 4 reports the results of our analysis, while section 5 concludes.

\section{On Housing Taxation in Italy}

In this section we briefly describe how the tax system on housing should be defined from a normative point of view, and how this actually translates into the provisions of the Italian Tax Code. Following the simplest approach (e.g., Rosen, 1985; Quigley, 2008), let $V$ be the market value of a given dwelling. If $i$ is the market interest rate (which we assume to be constant over time, in order to simplify the argument), then $R=V i$ is the gross imputed life annuity on the dwelling. To obtain the net imputed rent, also the maintenance costs $(M A)$, the depreciation costs $(D)$, and the interests paid on mortgage (MI) need to be considered, so that $R^{N}=R-M A-D-M I$. It is this net rent $R^{N}$ that should be included in the tax base of the comprehensive Personal Income Tax (PIT from now on).

Current tax systems are usually far from this theoretical definition. In particular, equity considerations (as discussed above) usually give reasons for the introduction of large subsidies for housing. In the US, for instance, the property tax (formally defined as 
$T_{p}=t_{p} V$ ) is deductible from the net rent $R^{N}$; more importantly, $R^{N}$ is excluded from the PIT taxable income (e.g., Rosen, 1985; Poterba, 1992; Quigley, 2008). Moreover, both $V$ and $R$ considered by Tax Authorities are sluggish to adapt to changes in market conditions, so that the "exempted" tax base tends to increase when market is booming. Something similar is provided also by the Italian Tax Code. In principle, including a wide array of incomes categories (from wages and salaries to financial capital rents), but also figurative incomes like cadastral rents, the Italian PIT (or IRPEF) should be a comprehensive income tax à la Schanz-Haig-Simons. In practice, however, since many income sources are taxed under a separate regime, other sources are highly underestimated or totally exempted, the Italian PIT is very far from the theory. The differences with respect to the theoretical definition of a comprehensive income tax are magnified in the context of housing taxation. Incomes from dwellings are determined in different ways according to the kind of use, and they are imputed to each owner (or life tenant) according to her percentage of ownership. Current rules in the Tax Code identify income for the taxpayer dwelling as the 'cadastral' income, i.e. a hypothetical imputed rent based on the property description and valuation listed in the local Land Register, the so-called Nuovo Catasto Edilizio Urbano. This was introduced in 1939, revising old cadastral incomes. Valuations were then updated several times afterwards: the last revision has been made in 1990 according to average market values in 1988-1989, and these values were made effective from 1992, so that those included in the tax base were largely different from current market values already at that time, in fact exempting a large share of the potential tax base. ${ }^{2}$ Income from unoccupied or holiday homes is equal to 'cadastral' income augmented by one third, so it is largely different from market values as well. On the contrary, income from rented dwellings is defined on a cash basis, and - leaving aside tax evasion - the tax base is equal to 85 percent of the actual cashed rent.

These general rules need a specification for the main residence, which is - according to Italian rules - the dwelling where the household actually lives. Though greatly underestimated, the income from the main residence is considered as part of the PIT

\footnotetext{
${ }^{2}$ As we will discuss below, according to our estimates the taxable rent $R^{t}$ according to current tax rules (i.e., the 'cadastral' income) is about 8 percent only of the net rent $R$.
} 
gross income for homeowners, but it can be fully deducted starting from 2001. Hence, the main residence is basically exempted from the PIT. As in other countries, the main residence for owner-occupiers is favoured also along other dimensions. Indeed, some expenditures in purchasing or in restructuring the main residence allow the owner a tax credit. In particular, a tax credit of 19 percent of the yearly paid interests (up to 687 euro) is allowed when funding the purchase through a mortgage (hence, $c^{M I}=0.19 \times M I$ ). A tax credit is available also for restructuring expenditures: the total expenditure (up to 48,000 euro from 2003 and up to about 77,000 euro before 2003) has to be split in 10 years (which is the conventional length of the amortization schedule defined by the law); every year a 41 percent (or 36 percent depending on the year the expenditure was incurred) tax credit is allowed (hence, $c^{M A}=0.41 \times M A$ ). On the contrary, for renters of the main residence, no tax credits were allowed up to 2007. It is only starting from 2008 that a tax credit related to personal income of the renter (up to about 30,000 euro) is allowed, which is higher for renters younger than 30 years old.

There are some important problems arising from the current house-PIT: first, the exemption of the main residence from any taxation coupled with tax credits for mortgage interests and maintenance expenditures create a subsidization policy toward housing investments, which presumably create inefficiencies in wealth allocation. In fact, financial rents from alternative assets bear some tax-burden. Broadly speaking, interests from private bonds are currently subject to a withholding tax, which will be raised from $12.50 \%$ to $20 \%$ in 2012 according to this year Budget Law. ${ }^{3}$ Dividends from stocks are subject to a similar rule in the case of 'non-qualified' stakes (i.e., stakes that do not guarantee the company control), whereas they are included in the PIT tax base in the case of 'qualified' stakes. Second, even if the main residence were included in the PIT tax base, the difference between the actual market values and the 'cadastral' incomes (i.e., $R-R^{t}$ ) has become particularly large given the recent boom in housing market (and it is still large despite the recent retrenchment of market prices), in fact exempting a large share of the potential taxable rent. This problem extends to the property tax, since the tax base of the dwelling income taxation is related to the tax base

\footnotetext{
${ }^{3}$ For very obvious reasons, Italian Treasury bonds will still be subjected to the $12.50 \%$ withholding tax.
} 
of the dwelling wealth taxation. ${ }^{4}$ We will consider both these two problems in the following empirical analysis.

\section{The Empirical Analysis}

\subsection{Data}

Together with the IT-SILC Survey, the Bank of Italy Survey of Household Income and Wealth (hereafter, SHIW-BI) is the most important Italian source of information for the analysis of the characteristics and the evolution of the Italian society. It is carried out every two years. The latest wave of the Survey has been published in 2010 and offers information on households' income and wealth in the year 2008, covering about 8,000 households and 20,000 individuals. The sample is representative of the Italian population, composed by 24 million households and 60 million individuals. According to definition in the survey, " $a$ household is a group of persons living together, whether related by kinship or not, who fulfill their needs by pooling all or part of the income earned by the members"; ..." the head of the household is defined as the person earning the highest income (excluding property income)” (Bank of Italy, 2010).

Relevant information in the SHIW-BI include: net income, net wealth, financial assets (bank deposits, government bonds, other securities and trade credits), real assets (real estate, business equity, valuables), and financial liabilities (liabilities towards banks, trade liabilities, liabilities towards other households). Differently from other countries, which consider the household as the tax unit, income is defined in Italy on an individual basis. Interests, dividends, financial assets and real estates information are available

\footnotetext{
${ }^{4}$ The Imposta Comunale sugli Immobili (ICI, Municipal Tax on Dwellings) is a property tax on each dwelling that has been introduced since 1993. Differently from the US case, the Italian property tax is not deductible from the PIT tax base. Tax revenues accrue directly to each Municipality where the buildings are located, and represent one of their major source of revenues. In theory, the ICI tax base should be the market value $V$ of the dwelling. In practice, this is not the case. The Land Register value of the dwelling is evaluated by simply multiplying cadastral income by $100: V^{t}=R^{t} \times 100$; hence, the value of the dwelling is equal to the perpetual annuity of the cadastral income with a 1 percent discount rate. Each Municipality can choose the tax rate in a range between a minimum of 4 per thousand and a maximum of 7 . The mean average tax rate is about 5-6 per thousand, so that ICI tax liability is effectively equal to 50-60 percent of the cadastral income $R^{t}$. As for the PIT, main residence for owner-occupiers is favoured also in the case of ICI. Up to 2007, a tax credit on the main residence was available. Starting from 2008, the main residence has been totally exempted (but for the luxury homes). Starting from January 2012, the main residence has been however included again in the ICI tax base. In particular, the tax base for these dwellings is obtained by multiplying the cadastral incomes by a flat 160 coefficient.
} 
only at the household level. However, by exploiting information on the ownership shares, it is possible to evaluate the real estates incomes also at the individual level ${ }^{5}$. Since our aim is to compare current provisions of the Tax Code with an alternative approach, which considers a 'true' imputed rent $R$ from owner-occupied dwelling, one main problem for our analysis concerns the definition of this imputed rent. There are several different methods to define $R$ (e.g., Frick and Grabka, 2003; Garner and Short, 2009): the market-value approach, the capital-market approach, the opportunity-cost approach, the selection/hedonic approach. The first is based on national accounts, and consider survey data on rents, including expenditures like water and lighting. The second basically considers the relationship $R=\rho V$, where $\rho$ is the current market interest rate on alternative use of capital. The third method - also known as the modified market-value approach - corrects the estimated market value by deducting interests payments and all relevant operating and maintenance costs, excluding heating. Finally, the fourth approach estimates a gross rent using a hedonic regression model, and then compute $R$ using estimated model coefficients for housing characteristics. All these approaches present drawbacks and limitations, so that there are no easy solutions to the problem of what approach actually choose. Here we define the net imputed rent (hereafter, IR) following a sort of modified market-value approach, also known as "reported rental equivalence" (Garner and Short, 2009). We start from gross IR, considering the value interviewees indicated in SHIW-BI answering to the following question: "Assuming you wanted to rent this dwelling, what monthly rent do you or your household think could be charged?"6. To obtain the net IR, we subtract mortgage interests and one tenth of maintenance expenditures ${ }^{7}$ from the gross IR. Unfortunately, we are not able to assess neither the differences with alternative methodologies, nor the bias in answering due to the presence of an extensive black market for rents (Reviglio, 1998). However, while there are some differences across different methods in the

\footnotetext{
${ }^{5}$ Notice that - according to the Italian tax law - children do not bear any special ownership shares of the dwellings where they live with their parents. In particular, in the SHIW-BI sample, about 50 percent of the dwellings are 100 percent owned by one component of the household (usually, the head), while most of the remaining are owned by two components (usually, the two members of the couple).

${ }^{6}$ This is exactly the same question asked in the US Consumer Expenditure Interview Survey. See Garner and Short (2009).

${ }^{7}$ Ten years is the conventional length of the amortization schedule defined by the Italian law.
} 
estimates of IR, and the "reported rental equivalence" is likely to produce upward biased estimates especially for low-income earners, Garner and Short (2009) have shown that the general conclusions in terms of distributional outcomes are not affected. This is reassuring for our following analysis.

\subsection{The Microsimulation Model}

The analysis of the redistributive effects of housing taxation is based on a microsimulation model that estimates all the most important taxes on housing characterizing the Italian fiscal system described above (technical details are available in Pellegrino et al., 2011). The model considers all incomes included in the PIT tax base, incomes exempt from taxes and incomes taxed under a separate regime in order to evaluate net and gross incomes earned by each person (which, according to the Italian rules, is the subject of taxation, even if belonging to a family). Once each individual incomes have been simulated, we then aggregate results at the household level. The gross disposable income is equal to the sum of gross PIT income, family benefits ${ }^{8}$, incomes exempt from taxation, gross incomes from financial assets, and gross incomes taxed under a separate regime. The net disposable income is equal to the gross disposable income net of all taxes; we subtract the mortgage interests to the result. Finally, in order to obtain the household equivalent disposable income, we adopt the Cutler Scale (CS), defined as: $C S=\left(N_{A}+.33 N_{C}\right)^{68}$ where $N_{A}$ and $N_{C}$ are respectively the number of adults and children within each household ${ }^{9}$.

Focusing on housing, the cadastral income - which is considered as the administrative imputed rent to be included in the gross income - is equal to the cadastral value of the dwelling divided by 100 . The problem is the estimation of the cadastral value of each dwelling. The National Land Agency estimates the number and the composition, as well as the overall cadastral value of dwellings (i.e., the overall ICI tax base). The SHIW-BI

\footnotetext{
${ }^{8}$ Family benefits represent the so-called Assegni al Nucleo Familiare, a very small cash transfer typical of the corporative Italian Welfare State, which varies with the number of children and income.

${ }^{9}$ Parameters of the Cutler Scale have been chosen in order to minimise re-ranking according to the 2008 tax rules. Of course, different equivalence scales have been proposed in the literature. However, the Cutler and Kats scale is the most general, since most of the other equivalence scales can be obtained by varying its parameters.
} 
dataset contains information on the current market value of each dwelling owned by households. We compare these two aggregate values in order to obtain the average underestimation of overall cadastral values with respect to overall market values. Then, we impute the same percentage of underestimation to the real value of each dwelling declared by each interviewed ${ }^{10}$. By dividing the result obtained by 100 , and using the percentage of ownership of each person within the household, we obtain the cadastral income included in the definition of individual PIT gross income.

The model "goodness-of-fit" is reassuring. Estimated revenues from the House-PIT on residential dwellings are about 3 billion euro in 2008, a value close to the figures provided by the Ministry of Finance. As discussed in depth in Pellegrino et al. (2011), the microsimulation model can then be used as a reliable tool for the analysis of housing taxation in Italy.

\section{Results}

\subsection{Some Preliminary Evidence: Tenure Status, Distribution and Allocation of Household Wealth}

The picture of the 24 million Italian households according to their tenure status using SHIW-BI data is in Table 1: 17 million (71.9 percent) are the owner-occupiers of their main residence or the life tenants ${ }^{11} ; 5$ million (22 percent) rent their residence ${ }^{12} ; 1.5$ million (6.2 percent) are rent-free tenants (and in 92 percent of the cases, the dwelling is owned by relatives or friends). Almost 70 percent of tenants rent their house from other households; 25.7 percent of tenants rent from public bodies, like the Istituto Autonomo Case Popolari (a locally funded Institute providing housing to the poor), but also Regions, Provinces, Municipalities; and 4 percent from private firms. Almost all the

\footnotetext{
${ }^{10}$ Notice that applying the same percentage of underestimation, we introduce a bias towards a more equal distribution of IR.

${ }^{11}$ Life tenants bear the right (which is called "usufruct") to use the dwellings for all their life. The owners retain in this case just the bare property.

12 Included in this category are also the households that rent their main residence " $a$ riscatto" (literally, "redemption agreement"). This means that the rental contract includes also a call option that allows the tenant to buy the house where she lives at a given price and date. Rents paid up to the maturity are subtracted from the market price to define the strike price.
} 
owner-occupiers are not burdened with a mortgage, while only a small percentage (13.7 percent) have a mortgage ${ }^{13}$.

Table 1: Households composition by tenure status (\%)

\begin{tabular}{lcc}
\hline \hline \multicolumn{1}{c}{ Tenure Status } & $\begin{array}{l}\text { Number of } \\
\text { households }\end{array}$ & Composition \\
\hline \hline Owner occupiers without mortgage or in usufruct & $14,877,542$ & 62.0 \\
\hline Owner occupiers with mortgage & $2,370,710$ & 9.9 \\
\hline Tenants or occupiers under redemption agreement & $5,280,728$ & 22.0 \\
\hline Rent-free tenants & $1,476,392$ & 6.2 \\
\hline \hline Total & $\mathbf{2 4 , 0 0 5 , 3 7 2}$ & $\mathbf{1 0 0 . 0}$ \\
\hline \hline
\end{tabular}

Source: Own calculations based on SHIW.

This picture fits fairly well with aggregate available data, and allows for a comparison with the situation of other Western countries. In particular, the share of households living in owner-occupied dwellings is similar to UK and the US, but very different from Germany, where only about 45 percent of households are owner-occupiers. This is reflected in the share of renters (including rent-free tenants), which are about 30 percent, while reaching a half in Germany. However, despite similarities with UK and US, Italian households are less indebted than their Anglo-Saxon counterparts: the share of owner-occupiers without a mortgage is three times bigger in Italy than in the UK and the US. More precisely, households with a mortgage are less than 10 percent in Italy and 50 percent in the UK and the US; they are about 25 percent in Germany (Frick and Grabka, 2003). The typical mortgage maturity and the maximum loan to value are also lower in Italy than in other countries (Bernardi and Poggio, 2004). Maturity is 10 years in Italy, 25 in the UK, up to 30 years in Germany, Netherlands and Norway. The maximum loan to value is $50 \%$ in Italy, $80 \%$ in Germany, and up to $100 \%$ in the UK. According to available estimates, the combination of a high percentage of owners and a low level of debt results in a mean (net) wealth of more than 225,000 USD per adult in Italy in 2010, which is quite close to estimates for UK (229,940 USD) and not so far from the US figure (263,213 USD) (Shorrocks et al., 2010). Besides the level of borrowing, another relevant difference between Italy and other countries is related to

13 Gale et al. (2007) suggest that mortgage interest deduction seems to have a small impact on homeownership. Similar results are provided for Italy by Jappelli and Pistaferri (2007). 
social housing: only 4.2 percent of households (one million tenants, about one fifth of total tenants) rent a council house at a subsidized rate. Very few countries (e.g., Germany and Portugal, with figures of 6.5 and 3.3 percent respectively) share this situation. On the contrary, most other EU countries have considerable higher percentages of households living in council houses: examples include Netherlands (34.6 percent), Sweden and Great Britain (21 percent), and Denmark (20 percent) (D’Ambrosio and Gigliarano, 2007).

Looking at the distribution of households by deciles of equivalent disposable gross income according to their tenure status in the SHIW data, the higher the decile, the higher the percentage of owner occupier within each decile (Table 2). However, since 62 per cent of household own their main residence without a mortgage, the gap between the bottom and the top decile is relatively small (54.8 percent to 68). The gap widens (4.5 percent to 17.7) for households with a mortgage. As expected, the percentage of tenants within each decile is decreasing: it is 33.2 percent in the bottom decile and 10.9 percent in the top one. The same picture is observed for rent-free tenants, with values ranging from 7.5 percent in the bottom decile to 3.4 in the top one. Again, these figures square quite nicely with aggregate available estimates on the distribution of wealth, according to which wealth is more equally distributed in Italy than in other comparable countries. In particular, median wealth is 50 percent of mean wealth in Italy, while only 34 percent in the UK (and much less so, at 20 percent, in the US; Shorrocks et al., 2010).

When considering age groups, not surprisingly, the share of owner-occupiers without a mortgage is increasing with the age of the household head, while the opposite occurs considering the share of households still paying off their mortgage. Moreover, the first age group considered here has a considerable high percentage of tenants (41.8), while it is only 14.1 percent for households in which the head is older than 65 (Table 3). 
Table 2: Distribution of households by decile of equivalent gross income

\begin{tabular}{|c|c|c|c|c|c|}
\hline \multicolumn{6}{|c|}{ Tenure status } \\
\hline Decile & $\begin{array}{c}\text { Owner } \\
\text { occupiers } \\
\text { without } \\
\text { mortgage or } \\
\text { in usufruct }\end{array}$ & $\begin{array}{c}\text { Owner } \\
\text { occupiers } \\
\text { with } \\
\text { mortgage }\end{array}$ & $\begin{array}{l}\text { Tenants or } \\
\text { occupiers } \\
\text { under } \\
\text { redemption } \\
\text { agreement }\end{array}$ & $\begin{array}{c}\text { Rent-free } \\
\text { tenants }\end{array}$ & Total \\
\hline 1 & 54.8 & 4.5 & 33.2 & 7.5 & 100.0 \\
\hline 2 & 54.8 & 5.5 & 28.8 & 11.0 & 100.0 \\
\hline 3 & 60.9 & 4.9 & 27.5 & 6.7 & 100.0 \\
\hline 4 & 61.6 & 9.0 & 23.7 & 5.6 & 100.0 \\
\hline 5 & 60.1 & 8.2 & 24.7 & 6.9 & 100.0 \\
\hline 6 & 63.5 & 6.4 & 23.1 & 7.0 & 100.0 \\
\hline 7 & 65.7 & 11.4 & 18.1 & 4.9 & 100.0 \\
\hline 8 & 64.2 & 14.8 & 16.2 & 4.9 & 100.0 \\
\hline 9 & 66.3 & 16.4 & 13.8 & 3.5 & 100.0 \\
\hline 10 & 68.0 & 17.7 & 10.9 & 3.4 & 100.0 \\
\hline Total & 62.0 & 9.9 & 22.0 & 6.2 & 100.0 \\
\hline
\end{tabular}

Source: Own calculations based on SHIW.

Table 3: Distribution of Households by age group

\begin{tabular}{cccccc}
\hline \hline Age group & \multicolumn{5}{c}{ Tenure status } \\
\hline \hline & $\begin{array}{c}\text { Owner } \\
\text { occupiers } \\
\text { without } \\
\text { mortgage or } \\
\text { in usufruct }\end{array}$ & $\begin{array}{c}\text { Owner } \\
\text { occupiers } \\
\text { with } \\
\text { mortgage }\end{array}$ & $\begin{array}{c}\text { Tenants or } \\
\text { occupiers } \\
\text { under } \\
\text { redemption } \\
\text { agreement }\end{array}$ & $\begin{array}{c}\text { Rent-free } \\
\text { tenants }\end{array}$ & Total \\
\hline \hline$\leq \mathbf{3 5}$ & 30.2 & 17.0 & 41.8 & 10.9 & 100.0 \\
\hline$>\mathbf{3 5} \mathbf{\&} \leq \mathbf{6 5}$ & 58.1 & 13.0 & 22.4 & 6.5 & 100.0 \\
\hline$>\mathbf{6 5}$ & 80.5 & 1.5 & 14.1 & 3.8 & 100.0 \\
\hline \hline Total & $\mathbf{6 2 . 0}$ & $\mathbf{9 . 9}$ & $\mathbf{2 2 . 0}$ & $\mathbf{6 . 2}$ & $\mathbf{1 0 0 . 0}$ \\
\hline \hline
\end{tabular}

Source: Own calculations based on SHIW.

\subsection{The Distribution of Main Residence Cadastral Incomes and Imputed Rents}

The main residence cadastral income $R^{t}$ (the 'administrative' imputed rent) is very low with respect to the net IR (the 'market' imputed rent): the mean value of the former is 544.7 euro, while the mean of the latter is about twelve times higher, equal to 6,884 euro (Table 4). Both $R^{t}$ and net IR similarly increase with respect to income deciles: the 
cadastral income is 370.6 euro in the bottom decile and only 920.5 euro (about 2.5 times) in the top one. The corresponding values for the net IR are 4,813 and 11,046 (about 2.3 times), respectively. A very different picture emerges whenever they are evaluated with respect to the equivalent disposable gross income: on average, $R^{t}$ is only 1.4 percent of the gross income, while the net IR is about one fifth $^{14}$.

Table 4: Value of main residence cadastral income by decile of household equivalent gross disposable income

\begin{tabular}{cccccc}
\hline \hline & \multicolumn{2}{c}{ Cadastral income } & \multicolumn{2}{c}{ Net IR } \\
\hline \hline Decile & $\begin{array}{c}\text { Percentage of } \\
\text { households } \\
\text { with positive } \\
\mathbf{R}\end{array}$ & $\begin{array}{c}\text { Average } \\
\text { value (euro) }\end{array}$ & $\begin{array}{c}\text { Average } \\
\text { value / } \\
\text { household } \\
\text { income }\end{array}$ & $\begin{array}{c}\text { Average } \\
\text { value (euro) }\end{array}$ & $\begin{array}{c}\text { Average } \\
\text { value / } \\
\text { household } \\
\text { income }\end{array}$ \\
\hline \hline $\mathbf{1}$ & 59.3 & 370.6 & 4.3 & $4,812.9$ & 56.2 \\
\hline $\mathbf{2}$ & 60.1 & 376.2 & 2.7 & $4,796.0$ & 34.4 \\
\hline $\mathbf{3}$ & 65.8 & 368.5 & 2.1 & $4,735.2$ & 27.3 \\
\hline $\mathbf{4}$ & 70.6 & 455.3 & 2.1 & $6,025.3$ & 28.7 \\
\hline $\mathbf{6}$ & 68.4 & 459.6 & 1.7 & $6,335.4$ & 23.8 \\
\hline $\mathbf{7}$ & 69.9 & 515.4 & 1.7 & $6,508.8$ & 21.6 \\
\hline $\mathbf{8}$ & 76.7 & 552.2 & 1.5 & $7,091.0$ & 19.3 \\
\hline $\mathbf{9}$ & 79.0 & 598.8 & 1.4 & $7,464.1$ & 17.3 \\
\hline $\mathbf{1 0}$ & 82.6 & 656.4 & 1.2 & $8,146.9$ & 15.1 \\
\hline \hline Total & 85.7 & 920.5 & 0.9 & $11,046.4$ & 10.5 \\
\hline \hline $\mathbf{7 1 . 8}$ & $\mathbf{5 4 4 . 7}$ & $\mathbf{1 . 4}$ & $\mathbf{6 , 8 8 3 . 9}$ & $\mathbf{1 8 . 0}$ \\
\hline
\end{tabular}

Source: Own calculations based on SHIW.

Moreover, even if both $R^{t}$ and IR are decreasing with income, the net IR is decreasing at a faster rate: it is 56.2 percent in the bottom decile and only 10.5 percent in the top one (about 6 times). The corresponding values for $R^{t}$ are 4.3 and 0.9 percent, respectively (about 4 times). According to these results, whenever the net IR is considered as a part of the PIT taxable income, overall inequality is expected to decrease.

\footnotetext{
${ }^{14}$ The ratio is computed only on households with a positive rent, i.e. it is conditional on being an homeowner. It appears to be quite different from other countries like UK and the US, not to say (West) Germany. According to Frick and Grabka (2003), in 1998 (1997 for US), IR as a percentage of postgovernment income (computed on owner-occupiers only) was $13 \%$ in UK, $13.5 \%$ in the US, and $8.7 \%$ in (West) Germany. Most of the difference is likely to be due to the sharp increase in housing prices experienced during the first decade of the new century.
} 
This is indeed the case. Consider Table 5, first row: let the 2008 overall household average gross income be 100 when excluding IR. Then, the mean gross income is about 129.5 for owner occupiers with a mortgage, and 104.7 for owner occupiers without mortgage; on the contrary, it is considerable lower for tenants (78.6) and for rent-free tenants (82). As suggested for instance by the Canberra Group (2001), let us now consider a broader definition of gross income, which includes also the net imputed rent IR from owner-occupied dwellings, as a better measure of wellbeing. The relative positions are very different whenever the net IR is considered as a component of the gross income (Table 5, second row): with respect to the current situation, the overall gross income is 113.3 , and it raises up to 124.4 for owner occupiers without mortgage and to 139.9 for owner occupiers with a mortgage. Of course, as long as the other two groups considered here are not affected by the imputed rent, their income positions do not change with respect to the situation where IR is excluded from the gross income definition.

As already observed in other studies (Frick and Grabka, 2003; D’Ambrosio and Gigliarano, 2007), the inclusion of net IR yields a considerable reducing effect on income inequality (Table 5, last two rows): Gini coefficient for equivalent household disposable gross income is 0.37815 excluding the net IR and decreases to 0.36469 including the net IR in the gross income definition. By considering the owner occupiers without mortgage, the Gini coefficient falls from 0.37731 to 0.34649 , whilst the corresponding values for owner occupiers with a mortgage are 0.35840 and 0.34950 , respectively.

Similar comments emerges also when decomposing population by age groups. Relative income positions when excluding IR are: 89.4 if the head of the household is 35 or younger, 106.9 if she is in the group 35-65, and 91.1 if she is older than 65 (Table 6, first row). With the inclusion of the net IR, the corresponding values are 96.6, 119.4 and 107.9, respectively (Table 6, second row). Clearly, as the share of owner-occupiers households increases with age, the higher variations of the Gini coefficient are registered in the top two age classes if net IR is considered, whilst the variation in the first age class is relatively small (Table 6, last rows). 


\subsection{The Distributional Effects of Taxing Imputed Rents}

As discussed above (Sec. 2), the actual taxation of housing income in Italy is particularly favorable to owner-occupiers. Income from the main residence is totally exempted. Even if it were taxed, the administratively defined imputed rent (the 'cadastral' income) is quite far from market imputed rent (Table 4). This generous tax treatment is likely to generate inefficiencies in the composition of wealth portfolios, resulting in a stronger share of households capital invested in housing with respect to alternative assets, like stocks and bonds (which are subject to a withholding tax, or are taxed within the PIT). Indeed, according to Sierminska et al. (2008), Italy is a country where the share of households wealth invested in housing (net of debt) is the highest among several western countries (including Germany, UK and US). On the contrary, Italian families invest a mere one percent in stocks, the lowest percentage among the same group of countries.

However, these (presumably) consistent allocative inefficiencies can be the price to be paid in order to foster equity. To judge the current tax system from this point of view, we need to assess its redistributive effect compared to alternative systems. In particular, we explore here what will happen to income distribution if we consider 'market' imputed rent in the PIT taxable income. ${ }^{15}$ According to most of the literature, excluding imputed rent amount to a subsidy for owner-occupation, and it is likely to favor the highest income groups (e.g., Aaron, 1970; Rosen, 1985). Including imputed rent in the tax base should then be equality enhancing. The following exercises consider four groups of households by their tenure status: owner occupiers without mortgage or life tenants (group 1); owner occupiers with mortgage (group 2); tenants (group 3); rent-free tenants (group 4). According to the current Tax Code, only households belonging to group 1 and 2 have a positive cadastral income from their main residence, which is

\footnotetext{
${ }^{15}$ As observed originally by Goode (1960), taxing imputed rents will involve administrative difficulties, like the measurement of certain deductible expenses (for instance, how to distinguish between repairs and permanent improvements when setting annual depreciation allowances?), and the upkeep of estimates in period of rapid changes in housing values. However, these difficulties are no less than those actually faced by current tax systems in measuring appropriately income.
} 
however totally exempted. We keep this in mind when simulating taxes on the imputed rent.

\subsubsection{Alternative reforms of housing taxation including IR}

When moving from gross to net income, we need to take into account how income is taxed within the PIT. We compare here the current situation (in which the main residence is basically exempted), with alternative systems based on the net IR, which would make tax-neutral the choice of investing in stocks or bonds with respect to houses. In particular, we design two broad alternative reforms, one which considers the net IR in the PIT tax base (as for certain dividends from stocks), and another which introduce a $20 \%$ withholding tax also for the net IR (like for interests accruing from bonds). As a mnemonic for these rules, we name the former stock-neutral reform and the latter bond-neutral reform. Of course, taxing net IR from owner-occupied dwellings would increase PIT revenues; but this will alter the assessment of the redistributive effect of the actual tax system by modifying the overall monetary net income. To avoid this problem, we then fix tax revenues at the current level, and ask what reduction in tax rates this will allow. For each reform, we consider three different scenarios. The first one (SCENARIO 1) considers available results on labour supply elasticities (Aaberge et al., 1999), and try to improve income growth by an higher reduction in marginal tax rates for low income brackets ${ }^{16}$. A second scenario (SCENARIO 2) considers a flat reduction in marginal rates on all brackets. Finally, the third scenario (SCENARIO 3) takes into account potential liquidity problems for low income households stemming from including a figurative income in the tax base. This is obtained by sterilizing the increase in taxes due to the inclusion of IR in the PIT tax base by means of a 20,000 euro tax credit for homeowners only, which is linearly decreasing with respect to gross income up to 10,000 euro. The reduction in the level of marginal tax rates would be sizable in both reforms, for all the three scenarios (Table 7a and 7b). Considering the stock-neutral reform first, it could be possible to reduce the marginal tax rates by more than 5 percentage points on the first bracket (which includes $47.85 \%$ of all the

\footnotetext{
${ }^{16}$ Besides the idea of making investments in different assets tax-neutral, the increase in GDP growth via a reduction in taxes is indeed one of the main reasons to implement a reform of housing taxation in Italy. For an analysis of the political viability of such a reform, see Pellegrino and Turati (2011).
} 
taxpayers), by 5 percentage points on the second one (37.26\% of taxpayers), by 4 points on the third (11.45\% of taxpayers), by 2 points on the fourth (1.69\% of taxpayers), and by 1 point on the top one (1.75\% of taxpayers) under SCENARIO 1 . The flat reduction under SCENARIO 2 would amount to $4.75 \%$ cut for all brackets, while SCENARIO 3 would be characterized by the same schedule we obtain for SCENARIO 1 augmented by $0.20 \%$ in all rates (because of the tax credit for low income taxpayers). Since a withholding tax is applied also to housing, tax rates cuts obtainable considering the bond-neutral reform would be clearly lower than in the stock-neutral reform. But it would still be possible under SCENARIO 1 to reduce by 4.51 percentage points the tax rate of the first income bracket, and leave the tax rate for the top one unchanged with respect to the original schedule. The flat reduction under SCENARIO 2 would amount to 3.55\% in this case, while - under SCENARIO 3 - we would increase by about $0.40 \%$ the tax rate for the top income bracket in order to cut the one of the first bracket by $4.14 \%$.

\subsubsection{Assessing the distributive impact of the reforms: Net income including the IR from owner-occupied dwellings}

Having defined the alternative reforms of housing taxation, we now move to the analysis of the distributional impact of taxing IR. To make a comparison with the present situation, we consider two different definitions of the current net income: a first one excluding the net IR (A), and a second one including the net IR (B). Comparing (A) with (B) allows us to evaluate the distributional impact of adding IR to the net income distribution, an exercise mirroring the one examined in the previous Section 4.2 on gross income. Comparing (B) with the net incomes originating under the two reforms allows us to assess the distributional impact of taxing IR when the definition of income is fixed and includes $I R^{17}$. Results are fairly similar across scenarios for the stockneutral reform and the bond-neutral reform (Table 8a and 8b). Let the 2008 overall average net income without IR be 100. The overall net income including IR is 118.6, and decreases to about 117 under both reforms and the three scenarios. As for the relative income positions (Table 8a and 8b, first four rows), owner occupiers without a mortgage observe an increase in their income from 105.8 to 133.4 when adding net IR,

\footnotetext{
${ }^{17}$ We thank the Editor and an anonymous referee for suggesting this approach.
} 
to about 129 under the two reforms. The corresponding figures for owner occupiers with a mortgage are 111, 126.5 and about 124, respectively. Also renters and rent-free tenants could benefit from cuts in marginal tax rates, since their tax base is unchanged. In particular, income for renters raises from 82.9 to between 85.9 and 87.2, while for rent-free tenants we observe an increase from 84.8 to between 87.9 to 89.3.

As for inequality (Table 8a and 8b, last four rows), we first confirm the inequality reducing effect of including IR in the definition of income: the Gini coefficient drops from 0.32748 when excluding IR to 0.32213 when including IR. More interestingly, with respect to the current net income including IR, we observe a reduction in the Gini coefficients also when considering almost all the alternative reform scenarios. Only in the bond-neutral reform, SCENARIO 2, the Gini increases from 0.32213 to 0.32460 , because of the flat reduction of all marginal tax rates and the $20 \%$ withholding tax on the net IR for all taxpayers. In both the stock-neutral and the bond-neutral reform, the largest reduction in inequality would be observed when including IR in the PIT tax base, and contemporaneously allowing for a tax credit for the poorest owner occupiers. In particular, considering the stock-neutral reform, the Gini drops from 0.32213 to 0.31627 under SCENARIO 3; the corresponding reduction considering the bond-neutral reform is from 0.32213 to 0.31936 . Results are less categorical when considering separately each group of taxpayers by tenure status. For instance, Gini coefficient falls for owner occupiers without a mortgage under SCENARIO 1 and SCENARIO 3 in the case of the stock-neutral reform, while it increases under all scenarios in the case of the bond-neutral reform.

Interesting conclusions emerge also when analyzing results by age groups (Table 9a and $9 \mathrm{~b}$, last four rows). As the share of owner occupiers is increasing with age, the largest drop in inequality is observed for the oldest age groups under both reforms. More precisely, for people aged 65 and over, the Gini coefficient moves from 0.32213 to 0.31627 (stock-neutral reform, SCENARIO 3), and 0.31936 (bond-neutral reform, SCENARIO 3). For those aged less than 35 years, the Gini drops from 0.29405 to 0.28938 (stock-neutral reform, SCENARIO 3), and 0.29144 (bond-neutral reform, SCENARIO 3).

Overall, then, our analysis shows that the current system of housing taxation is as inefficient as it is inequitable. It is inefficient since it distorts the allocation of wealth 
among different assets in favor of housing; it is inequitable since a reduction in the Gini coefficient can be obtained by appropriately taxing the IR, hence, contemporaneously increasing efficiency. However, as we already observed, despite these conclusions, the taxation of IR can pose severe potential liquidity problems, especially for low income households. This suggests to consider also net cash incomes to properly assess the distributive impact of the reforms. In particular, given the significant change in the tax base for some taxpayers, it is interestingly to understand how changes in tax liabilities are distributed across deciles. This is what we do next.

\subsubsection{A further assessment of the distributive impact: changes in tax liabilities for individual taxpayers}

As suggested by the Canberra Group (2001), the broad definition of income we considered so far - one that includes also figurative rents from owner-occupied dwellings - is not a proper indicator of wellbeing. Our analysis shows that taking into account also IR will reduce the Gini index, both considering gross and net incomes. We also showed that taxing IR will further improve the Gini coefficient, allowing for additional reductions in inequality. However, including IR in the tax base would significantly affect the tax base for some taxpayers and, correspondingly, the tax liability, so that one may want to analyse also net cash income as a further indicator to assess the distributional impact of the reforms. Notice that taking into account cash incomes amounts to take into account changes in tax liabilities with respect to the current situation. In other words, to identify gainers and losers across deciles under different scenarios. Notice also that here the analysis is based on individuals. This is because the tax unit according to the Italian Tax Code is the individual and not the household.

In general, given the reduction in marginal tax rates following the enlargement of the tax base, we expect taxpayers to obtain a reduction of their tax burden on labour incomes, and an increase of their burden because of the IR from dwellings. Taxpayers will then gain either because they are not owner occupiers and they just have labour incomes, or because the increase in the tax liability due to IR is smaller than the reduction in the burden on labour incomes. Hence, labour incomes are relatively more 
important than rents from dwellings, something which is likely to be true for richer taxpayers than for poorer ones.

Our estimates suggest that this intuition is substantially correct. Without allowing a tax credit for housing rents, low income taxpayers would be severely affected by including IR in the tax base. The share of losers in the bottom decile is about 55\% under both SCENARIO 1 and 2 when considering the stock-neutral reform, and increases up to 73\% when considering the bond-neutral reform ${ }^{18}$ (Tables 10a and 10b). Losses for these taxpayers under these scenarios amount to about their whole income, definitely worsening their situation (Tables 11a and 11b). When allowing for a tax credit (SCENARIO 3), the share of losers in the bottom decile considerably reduces to $3.5 \%$ under the stock-neutral reform, and 8.2\% under the bond-neutral reform. But (average) losses are possibly even larger now for those taxpayers with relatively large IR with respect to PIT gross income, which opens the door to the question of whether people who have little current income but substantial (housing) wealth are to be considered poor $^{19}$. Most of the winners are instead concentrated from the $6^{\text {th }}$ to the $8^{\text {th }}$ decile of the income distribution. Between 60 and 70 percent of taxpayers in these deciles will gain from the reforms irrespective of the scenario considered. The average gain will be around 3 to $5 \%$ of PIT gross income.

When considering age groups, results are pretty much consistent across reforms. The life-cycle perspective of real capital accumulation, which makes IR relatively more important than labour incomes when age increases, is pretty much clear from Tables 12a and $12 \mathrm{~b}$. The share of losers is clearly increasing with age, while the share of winners show the opposite variation. In particular, about $70 \%$ of young taxpayers (less than 35 years old) will gain from the reforms, irrespective of the specific rules implemented; the share of losers is instead between 10 and 16\% depending on the specific scenario considered. On the contrary, only around $30 \%$ of the elderly (more than 65 years old)

\footnotetext{
${ }^{18}$ Notice that the share of losers is higher than the share of owner occupiers households. This is because some dwellings are jointly owned by different members of the family.

${ }^{19}$ On this specific point, UK is not much different than Italy given the high proportion of owner occupiers. See the discussion in Mirrlees et al. (2011) for a proposal of reforming housing taxation in the UK, which shares some features of the exercise proposed here. However, as already discussed, the distribution of wealth is relatively less concentrated in Italy than in the UK, making the redistributive consequences of including IR in the PIT larger.
} 
will gain from the reforms, again irrespective of the specific hypotheses made. The share of losers is between $45 \%$ of these taxpayers under SCENARIO 3 in the stock-neutral reform, and 60\% under SCENARIO 2 in the bond-neutral reform. Unsurprisingly, average gains and losses as a percentage of PIT gross income are quite smaller with respect to what one can observe looking at income deciles (Tables 13a and 13b). For instance, considering SCENARIO 1 in the stock-neutral reform, average gains for young taxpayers are $4.6 \%$ of PIT gross income, while average losses amount to 5.7\%. The corresponding figures for the elderly are $2.9 \%$ and $6.1 \%$ respectively. When looking at age groups, the main conclusion is then the following: favoring owner-occupiers by excluding IR from the PIT tax base amounts to favoring the elderly who accumulated a real capital. This is worrisome for the younger generations, especially given the sharp increase in housing prices and the corresponding increase in rents, the lack in Italy of an adequate housing policy, and the liberalization of the mortgage market (e.g. Berloffa and Villa, 2010). From the point of view of wellbeing, is it then fair or not to include IR in the PIT tax base? Let us follow the original contribution by Goode (1960) and take for instance two individuals, A and B. A obtains a 35,000 euro income from labour, and rents the main residence where she lives by paying 5,000 euro per year; while $\mathrm{B}$ has a pension of 30,000 euro and lives in a dwellings with a figurative income of 5,000 euro per year with exactly the same characteristics of the one rented by A. According to the current rules, A will pay more taxes than B, but it is difficult to sustain that B's welfare is lower than A's. If this is true, then we should consider IR to evaluate the income position of each taxpayer. And in this case, our analysis shows that moving to IR leads to a reduction of the Gini coefficient while contemporaneously improving efficiency in wealth allocation. 
Tab. 5: Gross income by tenure status

\begin{tabular}{|c|c|c|c|c|c|}
\hline & \multicolumn{5}{|c|}{ Tenure status } \\
\hline Gross income & $\begin{array}{c}\text { Owner } \\
\text { occupiers } \\
\text { without } \\
\text { mortgage } \\
\text { or in } \\
\text { usufruct }\end{array}$ & $\begin{array}{c}\text { Owner } \\
\text { occupiers } \\
\text { with } \\
\text { mortgage }\end{array}$ & $\begin{array}{c}\text { Tenants or } \\
\text { occupiers } \\
\text { under } \\
\text { redemption } \\
\text { agreement }\end{array}$ & $\begin{array}{c}\text { Rent-free } \\
\text { tenants }\end{array}$ & Total \\
\hline 2008 mean income & 104.7 & 129.5 & 78.6 & 82.0 & 100.0 \\
\hline Mean income if net IR were taxed & 124.4 & 139.9 & 78.6 & 82.0 & 113.3 \\
\hline Gini coefficient for the 2008 distribution & 0.37731 & 0.35840 & 0.34983 & 0.37725 & 0.37815 \\
\hline Gini coefficient for the distribution with net IR & 0.34649 & 0.34950 & 0.34983 & 0.37725 & 0.36469 \\
\hline
\end{tabular}


Tab. 6: Gross income by age groups

\begin{tabular}{|c|c|c|c|c|}
\hline \multirow[b]{2}{*}{ Gross income } & \multicolumn{4}{|c|}{ Age group } \\
\hline & $\leq 35$ & $>35 \& \leq 65$ & $>65$ & Total \\
\hline 2008 mean income & 89.4 & 106.9 & 91.1 & 100.0 \\
\hline Mean income if net were taxed & 96.6 & 119.4 & 107.9 & 113.3 \\
\hline Gini coefficient for the 2008 distribution & 0.33253 & 0.37800 & 0.38206 & $\mathbf{0 . 3 7 8 1 5}$ \\
\hline Gini coefficient for the distribution with net IR & 0.32560 & 0.36880 & 0.36177 & 0.36469 \\
\hline
\end{tabular}

Source: Own calculations based on SHIW. 
Table 7a: Tax brackets and marginal tax rates - "Stock-neutral reform"

\begin{tabular}{|c|c|c|c|c|c|c|c|c|c|}
\hline \multirow{2}{*}{\multicolumn{2}{|c|}{ Tax base (euro) }} & \multirow{3}{*}{$\begin{array}{c}\begin{array}{c}\text { Percentage } \\
\text { of taxpayers }\end{array} \\
47.9\end{array}$} & \multirow{3}{*}{$\begin{array}{c}2008 \\
\begin{array}{c}\text { Tax rate } \\
(\%)\end{array} \\
23\end{array}$} & \multicolumn{2}{|c|}{ SCENARIO 1} & \multicolumn{2}{|c|}{ SCENARIO 2} & \multicolumn{2}{|c|}{$\begin{array}{c}\text { SCENARIO } 3(10,000 \\
\text { euro) }\end{array}$} \\
\hline & & & & Tax rate $(\%)$ & Difference & Tax rate $(\%)$ & Difference & Tax rate $(\%)$ & Difference \\
\hline Up to & 15,000 & & & 17.66 & 5.34 & 18.25 & 4.75 & 17.86 & 5.14 \\
\hline 15,000 & 28,000 & 37.3 & 27 & 22 & 5 & 22.25 & 4.75 & 22.2 & 4.80 \\
\hline 28,000 & 55,000 & 11.5 & 38 & 34 & 4 & 33.25 & 4.75 & 34.2 & 3.80 \\
\hline 55,000 & 75,000 & 1.7 & 41 & 39 & 2 & 36.25 & 4.75 & 39.2 & 1.80 \\
\hline Above & 75,000 & 1.8 & 43 & 42 & 1 & 38.25 & 4.75 & 42.2 & 0.80 \\
\hline
\end{tabular}

Source: Own calculations based on SHIW. 
Table 7b: Tax brackets and marginal tax rates - "Bond-neutral reform"

\begin{tabular}{|c|c|c|c|c|c|c|c|c|c|}
\hline \multirow{2}{*}{\multicolumn{2}{|c|}{ Tax base (euro) }} & \multirow{3}{*}{$\begin{array}{c}\begin{array}{c}\text { Percentage } \\
\text { of taxpayers }\end{array} \\
47.9\end{array}$} & \multirow{3}{*}{$\begin{array}{c}2008 \\
\begin{array}{c}\text { Tax rate } \\
(\%)\end{array} \\
23\end{array}$} & \multicolumn{2}{|c|}{ SCENARIO 1} & \multicolumn{2}{|c|}{ SCENARIO 2} & \multicolumn{2}{|c|}{$\begin{array}{c}\text { SCENARIO } 3(10,000 \\
\text { euro) }\end{array}$} \\
\hline & & & & Tax rate $(\%)$ & Difference & Tax rate $(\%)$ & Difference & Tax rate $(\%)$ & Difference \\
\hline Up to & 15,000 & & & 18.49 & 4.51 & 19.45 & 3.55 & 18.86 & 4.14 \\
\hline 15,000 & 28,000 & 37.3 & 27 & 24 & 3 & 23.45 & 3.55 & 24.37 & 2.63 \\
\hline 28,000 & 55,000 & 11.5 & 38 & 36 & 2 & 34.45 & 3.55 & 36.37 & 1.63 \\
\hline 55,000 & 75,000 & 1.7 & 41 & 40 & 1 & 37.45 & 3.55 & 40.37 & 0.63 \\
\hline Above & 75,000 & 1.8 & 43 & 43 & $\mathbf{0}$ & 39.45 & 3.55 & 43.37 & -0.37 \\
\hline
\end{tabular}

Source: Own calculations based on SHIW. 
Table 8a: Net income by tenure status SCENARIO - "Stock-neutral reform"

\begin{tabular}{|c|c|c|c|c|c|}
\hline \multirow[b]{2}{*}{ Net income } & \multicolumn{5}{|c|}{ Tenure status } \\
\hline & $\begin{array}{c}\text { Owner } \\
\text { occupiers } \\
\text { without } \\
\text { mortgage } \\
\text { or in } \\
\text { usufruct }\end{array}$ & $\begin{array}{c}\text { Owner } \\
\text { occupiers } \\
\text { with } \\
\text { mortgage }\end{array}$ & $\begin{array}{c}\text { Tenants or } \\
\text { occupiers } \\
\text { under } \\
\text { redemption } \\
\text { agreement }\end{array}$ & $\begin{array}{c}\text { Rent-free } \\
\text { tenants }\end{array}$ & Total \\
\hline 2008 mean income & 105.8 & 111.0 & 82.9 & 84.8 & 100.0 \\
\hline 2008 mean income with net IR & 133.4 & 126.5 & 82.9 & 84.8 & 118.6 \\
\hline Mean income SCENARIO 1 & 128.8 & 124.5 & 87.2 & 89.3 & 116.8 \\
\hline Mean income SCENARIO 2 & 128.8 & 124.7 & 87.0 & 89.2 & 116.8 \\
\hline Mean income SCENARIO 3 (10,000 euro) & 128.8 & 124.3 & 87.0 & 89.1 & 116.7 \\
\hline "Gini coefficient for the 2008 distribution & 0.32511 & 0.34186 & 0.30224 & 0.32576 & 0.32748 \\
\hline Gini coefficient for the 2008 distribution with net IR & 0.29842 & 0.33503 & 0.30224 & 0.32576 & 0.32213 \\
\hline Gini coefficient for the SCENARIO 1 distribution & 0.29794 & 0.33556 & 0.30802 & 0.33035 & 0.31735 \\
\hline Gini coefficient for the SCENARIO 2 distribution & 0.30100 & 0.33969 & 0.30885 & 0.33219 & 0.32009 \\
\hline Gini coefficient for the SCENARIO 3 distribution (10,000 euro) & 0.29630 & 0.33477 & 0.30766 & 0.33004 & 0.31627 \\
\hline
\end{tabular}

Source: Own calculations based on SHIW. 
Table 8b: Net income by tenure status - "Bond-neutral reform"

\begin{tabular}{|c|c|c|c|c|c|}
\hline \multirow[b]{2}{*}{ Net income } & \multicolumn{5}{|c|}{ Tenure status } \\
\hline & $\begin{array}{c}\text { Owner } \\
\text { occupiers } \\
\text { without } \\
\text { mortgage } \\
\text { or in } \\
\text { usufruct }\end{array}$ & $\begin{array}{c}\text { Owner } \\
\text { occupiers } \\
\text { with } \\
\text { mortgage }\end{array}$ & $\begin{array}{c}\text { Tenants or } \\
\text { occupiers } \\
\text { under } \\
\text { redemption } \\
\text { agreement }\end{array}$ & $\begin{array}{c}\text { Rent-free } \\
\text { tenants }\end{array}$ & Total \\
\hline 2008 mean income & 105.8 & 111.0 & 82.9 & 84.8 & 100.0 \\
\hline 2008 mean income with net IR & 133.4 & 126.5 & 82.9 & 84.8 & 118.6 \\
\hline Mean income SCENARIO 1 & 129.4 & 124.2 & 86.2 & 88.2 & 116.9 \\
\hline Mean income SCENARIO 2 & 129.5 & 124.6 & 86.0 & 88.1 & 116.9 \\
\hline Mean income SCENARIO 3 (10,000 euro) & 129.6 & 123.9 & 85.9 & 87.9 & 116.9 \\
\hline "Gini coefficient for the 2008 distribution & 0.32511 & 0.34186 & 0.30224 & 0.32576 & 0.32748 \\
\hline Gini coefficient for the 2008 distribution with net IR & 0.29842 & 0.33503 & 0.30224 & 0.32576 & 0.32213 \\
\hline Gini coefficient for the SCENARIO 1 distribution & 0.30364 & 0.33785 & 0.30552 & 0.32795 & 0.32172 \\
\hline Gini coefficient for the SCENARIO 2 distribution & 0.30656 & 0.34219 & 0.30710 & 0.33054 & 0.32460 \\
\hline Gini coefficient for the SCENARIO 3 distribution (10,000 euro) & 0.29997 & 0.33674 & 0.30497 & 0.32738 & 0.31936 \\
\hline
\end{tabular}

Source: Own calculations based on SHIW. 
Table 9a: Net income by age groups - "Stock-neutral reform"

\begin{tabular}{|c|c|c|c|c|}
\hline \multirow[b]{2}{*}{ Net income } & \multicolumn{4}{|c|}{ Age group } \\
\hline & $\leq 35$ & $\begin{array}{c}>35 \& \leq \\
65\end{array}$ & $>65$ & Total \\
\hline 2008 mean income & 88.6 & 105.0 & 94.8 & 100.0 \\
\hline 2008 mean income with net IR & 98.8 & 122.6 & 118.3 & 118.6 \\
\hline Mean income SCENARIO 1 & 99.6 & 121.2 & 114.7 & 116.8 \\
\hline Mean income SCENARIO 2 & 99.4 & 121.3 & 114.6 & 116.8 \\
\hline Mean income SCENARIO 3 (10,000 euro) & 99.6 & 121.2 & 114.6 & 116.7 \\
\hline Gini coefficient for the 2008 distribution & 0.29634 & 0.33222 & 0.32055 & 0.32748 \\
\hline Gini coefficient for the 2008 distribution with net IR & 0.29405 & $\mathbf{0 . 3 2 9 7 1}$ & 0.3106 & 0.32213 \\
\hline Gini coefficient for the SCENARIO 1 distribution & 0.29058 & 0.32489 & 0.30558 & 0.31735 \\
\hline Gini coefficient for the SCENARIO 2 distribution & 0.29195 & 0.32789 & 0.30813 & 0.32009 \\
\hline Gini coefficient for the SCENARIO 3 distribution (10,000 euro) & 0.28938 & 0.32363 & 0.30488 & 0.31627 \\
\hline
\end{tabular}


Table 9b: Net income by age groups - "Bond-neutral reform"

\begin{tabular}{|c|c|c|c|c|}
\hline \multirow[b]{2}{*}{ Net income } & \multicolumn{4}{|c|}{ Age group } \\
\hline & $\leq 35$ & $\begin{array}{c}>35 \& \leq \\
65\end{array}$ & $>65$ & Total \\
\hline 2008 mean income & 88.6 & 105.0 & 94.8 & 100.0 \\
\hline 2008 mean income with net IR & 98.8 & 122.6 & 118.3 & 118.6 \\
\hline Mean income SCENARIO 1 & 99.1 & 121.4 & 114.9 & 116.9 \\
\hline Mean income SCENARIO 2 & 98.9 & 121.4 & 114.9 & 116.9 \\
\hline Mean income SCENARIO 3 (10,000 euro) & 99.0 & 121.3 & 115.1 & 116.9 \\
\hline Gini coefficient for the 2008 distribution & 0.29634 & 0.33222 & 0.32055 & 0.32748 \\
\hline Gini coefficient for the 2008 distribution with net IR & 0.29405 & $\mathbf{0 . 3 2 9 7 1}$ & 0.3106 & 0.32213 \\
\hline Gini coefficient for the SCENARIO 1 distribution & 0.29339 & 0.32870 & 0.31139 & 0.32172 \\
\hline Gini coefficient for the SCENARIO 2 distribution & 0.29514 & 0.33186 & 0.31396 & 0.32460 \\
\hline Gini coefficient for the SCENARIO 3 distribution (10,000 euro) & 0.29144 & 0.32667 & 0.30828 & 0.31936 \\
\hline
\end{tabular}


Table 10a: Winners and losers from the IRPEF reform in each decile (individual taxpayers) - "Stock-neutral reform"

\begin{tabular}{|c|c|c|c|c|c|c|c|c|c|}
\hline \multirow[b]{2}{*}{ Decile } & \multicolumn{3}{|c|}{ SCENARIO 1} & \multicolumn{3}{|c|}{ SCENARIO 2} & \multicolumn{3}{|c|}{ SCENARIO 3 (10,000 euro) } \\
\hline & Win & Indifferent & Lose & Win & Indifferent & Lose & Win & Indifferent & Lose \\
\hline 1 & 9.3 & 35.5 & 55.1 & 9.3 & 35.1 & 55.6 & 22.2 & 74.4 & 3.5 \\
\hline 2 & 8.3 & 71.6 & 20.1 & 8.2 & 70.2 & 21.6 & 12.5 & 76.1 & 11.4 \\
\hline 3 & 29.9 & 36.3 & 33.8 & 28.3 & 35.4 & 36.3 & 30.3 & 36.8 & 32.9 \\
\hline 4 & 48.1 & 12.0 & 39.9 & 44.5 & 11.9 & 43.5 & 46.9 & 12.0 & 41.1 \\
\hline 5 & 57.9 & 4.8 & 37.3 & 54.6 & 4.8 & 40.6 & 56.0 & 4.8 & 39.2 \\
\hline 6 & 64.6 & 2.3 & 33.2 & 60.8 & 2.3 & 36.9 & 63.7 & 2.3 & 34.1 \\
\hline 7 & 68.8 & 0.0 & 31.2 & 65.4 & 0.0 & 34.6 & 67.2 & 0.0 & 32.8 \\
\hline 8 & 67.2 & 0.2 & 32.5 & 64.8 & 0.2 & 35.0 & 66.1 & 0.2 & 33.7 \\
\hline 9 & 58.7 & 0.0 & 41.3 & 56.1 & 0.0 & 43.9 & 57.3 & 0.0 & 42.7 \\
\hline 10 & 59.9 & 0.0 & 40.1 & 63.9 & 0.0 & 36.1 & 57.1 & 0.0 & 42.9 \\
\hline All & 47.3 & 16.3 & 36.4 & 45.6 & 16.0 & 38.4 & 47.9 & 20.7 & 31.4 \\
\hline No. Taxpayers (ml) & 19.6 & 6.8 & 15.1 & 18.9 & 6.7 & 16.0 & 19.9 & 8.6 & 13.0 \\
\hline
\end{tabular}

Source: Own calculations based on SHIW. 
Table 10b Winners and losers from the IRPEF reform in each decile (individual taxpayers) - "Bond-neutral reform"

\begin{tabular}{|c|c|c|c|c|c|c|c|c|c|}
\hline \multirow[b]{2}{*}{ Decile } & \multicolumn{3}{|c|}{ SCENARIO 1} & \multicolumn{3}{|c|}{ SCENARIO 2} & \multicolumn{3}{|c|}{ SCENARIO 3 (10,000 euro) } \\
\hline & Win & Indifferent & Lose & Win & Indifferent & Lose & Win & Indifferent & Lose \\
\hline 1 & 9.3 & 17.7 & 73.0 & 9.3 & 17.7 & 73.0 & 21.9 & 70.0 & 8.2 \\
\hline 2 & 8.2 & 45.0 & 46.8 & 8.2 & 45.0 & 46.8 & 11.5 & 72.2 & 16.3 \\
\hline 3 & 29.9 & 23.3 & 46.7 & 27.4 & 23.3 & 49.3 & 30.9 & 29.6 & 39.6 \\
\hline 4 & 48.3 & 8.4 & 43.3 & 43.3 & 8.4 & 48.2 & 46.3 & 8.4 & 45.3 \\
\hline 5 & 60.0 & 3.6 & 36.4 & 54.4 & 3.6 & 42.0 & 57.7 & 3.6 & 38.7 \\
\hline 6 & 68.1 & 1.2 & 30.7 & 60.8 & 1.2 & 38.0 & 64.3 & 1.2 & 34.5 \\
\hline 7 & 69.4 & $\mathbf{0 . 0}$ & 30.6 & 64.4 & $\mathbf{0 . 0}$ & 35.6 & 67.9 & $\mathbf{0 . 0}$ & 32.1 \\
\hline 8 & 68.3 & 0.1 & 31.6 & 65.0 & 0.1 & 34.9 & 65.8 & 0.1 & 34.2 \\
\hline 9 & 66.6 & $\mathbf{0 . 0}$ & 33.4 & 63.6 & $\mathbf{0 . 0}$ & 36.4 & 62.5 & $\mathbf{0 . 0}$ & 37.5 \\
\hline 10 & 67.3 & 0.0 & 32.7 & 76.2 & 0.0 & 23.8 & 61.8 & $\mathbf{0 . 0}$ & 38.2 \\
\hline All & 49.5 & 9.9 & 40.5 & 47.3 & 9.9 & 42.8 & 49.0 & 18.5 & 32.4 \\
\hline No. Taxpayers (ml) & 20.6 & 4.1 & 16.8 & 19.6 & 4.1 & 17.8 & 20.4 & 7.7 & 13.5 \\
\hline
\end{tabular}

Source: Own calculations based on SHIW. 
Table 11a: Average gain (loss) from the IRPEF reform in each decile (individual taxpayers) - "Stock-neutral reform"

\begin{tabular}{|c|c|c|c|c|c|c|c|c|c|c|c|c|}
\hline & \multicolumn{4}{|c|}{ SCENARIO 1} & \multicolumn{4}{|c|}{ SCENARIO 2} & \multicolumn{4}{|c|}{ SCENARIO $3(10,000$ euro) } \\
\hline & & Win & & Lose & & Win & & Lose & & Win & & Lose \\
\hline Decile & Euro & $\begin{array}{l}\text { \% of actual } \\
\text { PIT gross } \\
\text { income }\end{array}$ & Euro & $\begin{array}{l}\text { \% of actual } \\
\text { PIT gross } \\
\text { income }\end{array}$ & Euro & $\begin{array}{c}\text { \% of actual } \\
\text { PIT gross } \\
\text { income }\end{array}$ & Euro & $\begin{array}{l}\text { \% of actual } \\
\text { PIT gross } \\
\text { income }\end{array}$ & Euro & $\begin{array}{c}\text { \% of actual } \\
\text { PIT gross } \\
\text { income }\end{array}$ & Euro & $\begin{array}{c}\text { \% of actual } \\
\text { PIT gross } \\
\text { income }\end{array}$ \\
\hline 1 & 42 & 5.2 & 688 & 92.0 & 37 & 4.7 & 709 & 94.4 & 67 & 8.8 & 2155 & 126.6 \\
\hline 2 & 265 & 4.8 & 917 & $\mathbf{1 7 . 3}$ & 246 & 4.5 & 921 & 17.2 & 306 & 5.8 & 1161 & 20.2 \\
\hline 3 & 367 & 4.1 & 823 & 9.4 & 354 & 4.0 & 842 & 9.5 & 370 & 4.2 & 864 & 9.8 \\
\hline 4 & 509 & 4.3 & 820 & 7.0 & 483 & 4.1 & 836 & 7.1 & 500 & 4.2 & 827 & 7.0 \\
\hline 5 & 633 & 4.3 & 870 & 5.9 & 586 & 4.0 & 895 & 6.1 & 625 & 4.2 & 866 & 5.9 \\
\hline 6 & 723 & 4.2 & 783 & 4.5 & 669 & 3.8 & 802 & 4.6 & 699 & 4.0 & 805 & 4.6 \\
\hline 7 & 811 & 4.0 & 993 & 5.0 & 748 & 3.7 & 999 & 5.0 & 788 & 3.9 & 994 & 5.0 \\
\hline 8 & 886 & 3.8 & 1161 & 5.0 & 806 & 3.5 & 1181 & 5.0 & 852 & 3.7 & 1180 & 5.0 \\
\hline 9 & 1086 & 3.7 & 1486 & 5.1 & 1029 & 3.5 & 1462 & 5.0 & 1053 & 3.6 & 1505 & 5.2 \\
\hline 10 & 1617 & 2.6 & 2291 & 3.8 & 2192 & 3.2 & 2045 & 4.1 & 1564 & 2.5 & 2277 & 3.9 \\
\hline Totale & 840 & 3.5 & 1090 & 5.7 & 890 & 3.5 & 1057 & 5.9 & 790 & 3.4 & 1206 & 5.2 \\
\hline
\end{tabular}

Source: Own calculations based on SHIW. 
Table 11b: Average gain (loss) from the IRPEF reform in each decile (individual taxpayers) - "Bond-neutral reform"

\begin{tabular}{|c|c|c|c|c|c|c|c|c|c|c|c|c|}
\hline & \multicolumn{4}{|c|}{ SCENARIO 1} & \multicolumn{4}{|c|}{ SCENARIO 2} & \multicolumn{4}{|c|}{ SCENARIO 3 (10,000 euro) } \\
\hline & & Win & & Lose & & "Win & & Lose & & "Win & & Lose \\
\hline Decile & Euro & $\begin{array}{l}\text { \% of actual } \\
\text { PIT gross } \\
\text { income }\end{array}$ & Euro & $\begin{array}{l}\text { \% of actual } \\
\text { PIT gross } \\
\text { income }\end{array}$ & Euro & $\begin{array}{c}\text { \% of actual } \\
\text { PIT gross } \\
\text { income }\end{array}$ & Euro & $\begin{array}{c}\text { \% of actual } \\
\text { PIT gross } \\
\text { income }\end{array}$ & Euro & $\begin{array}{l}\text { \% of actual } \\
\text { PIT gross } \\
\text { income }\end{array}$ & Euro & $\begin{array}{c}\text { \% of actual } \\
\text { PIT gross } \\
\text { income }\end{array}$ \\
\hline 1 & 35 & 4.4 & 736 & 94.0 & 28 & 3.5 & 737 & 94.1 & 24 & 3.2 & 1049 & 93.6 \\
\hline 2 & 233 & 4.3 & 764 & 14.0 & 191 & 3.5 & 768 & 14.1 & 205 & 3.9 & 1183 & 20.6 \\
\hline 3 & 324 & 3.6 & 745 & 8.6 & 280 & 3.2 & 737 & 8.5 & 302 & 3.4 & 840 & 9.5 \\
\hline 4 & 434 & 3.7 & 666 & 5.7 & 369 & 3.1 & 681 & 5.8 & 410 & 3.5 & 669 & 5.7 \\
\hline 5 & 527 & 3.6 & 675 & 4.6 & 438 & 3.0 & 700 & 4.7 & 492 & 3.3 & 682 & 4.6 \\
\hline 6 & 569 & 3.3 & 616 & 3.5 & 499 & 2.9 & 614 & 3.5 & 538 & 3.1 & 605 & 3.5 \\
\hline 7 & 638 & 3.2 & 705 & 3.5 & 564 & 2.8 & 715 & 3.6 & 578 & 2.9 & 741 & 3.7 \\
\hline 8 & 662 & 2.8 & 749 & 3.2 & 593 & 2.5 & 775 & 3.3 & 601 & 2.6 & 773 & 3.3 \\
\hline 9 & 746 & 2.6 & 803 & 2.8 & 726 & 2.5 & 799 & 2.8 & 686 & 2.3 & 814 & 2.8 \\
\hline 10 & 959 & 1.6 & 1189 & 1.9 & 1580 & 2.4 & 1159 & 2.4 & 820 & 1.4 & 1239 & 1.8 \\
\hline "Totale & 620 & 2.6 & 759 & 4.6 & 679 & 2.6 & $7 \mathbf{7 5 0}$ & 5.1 & 543 & 2.4 & 822 & 3.6 \\
\hline
\end{tabular}

Source: Own calculations based on SHIW. 
Table 12a: Winners and losers by age groups (individual taxpayers) - "Stock-neutral reform"

\begin{tabular}{cccccccccc}
\hline \hline & & SCENARIO 1 & & \multicolumn{3}{c}{ SCENARIO 2 } & \multicolumn{3}{c}{ SCENARIO 3 (10,000 euro) } \\
\hline \hline Age group & Win & Indifferent & Lose & Win & Indifferent & Lose & Win & Indifferent & Lose \\
\hline \hline$\leq 35$ & 69.7 & 16.2 & 14.1 & 69.1 & 16.1 & 14.8 & 71.3 & 18.8 & 10.0 \\
\hline$>35 \& \leq 65$ & 47.2 & 14.1 & 38.7 & 45.4 & 14.0 & 40.6 & 48.0 & 19.6 & 32.4 \\
\hline$>65$ & 31.3 & 21.0 & 47.7 & 29.0 & 20.4 & 50.6 & 30.8 & 24.5 & 44.7 \\
\hline \hline Total & 47.3 & 16.3 & 36.4 & 45.6 & 16.0 & 38.4 & 47.9 & 20.7 & 31.4 \\
\hline \hline
\end{tabular}

Source: Own calculations based on SHIW. 
Table 12b: Winners and losers by age groups (individual taxpayers) - "Bond-neutral reform"

\begin{tabular}{cccccccccc}
\hline \hline & & SCENARIO 1 & & & SCENARIO 2 & \multicolumn{3}{c}{ SCENARIO 3 (10,000 euro) } \\
\hline \hline Age group & Win & Indifferent & Lose & Win & Indifferent & Lose & Win & Indifferent & Lose \\
\hline \hline$\leq 35$ & 70.4 & 14.4 & 15.2 & 68.9 & 14.4 & 16.7 & 70.8 & 17.8 & 11.4 \\
\hline$>35 \& \leq 65$ & 49.9 & 8.8 & 41.3 & 48.0 & 8.8 & 43.1 & 49.6 & 17.0 & 33.5 \\
\hline$>65$ & 33.8 & 9.2 & 57.1 & 30.0 & 9.2 & 60.8 & 32.3 & 22.4 & 45.3 \\
\hline \hline Total & 49.5 & 9.9 & 40.5 & 47.3 & 9.9 & 42.8 & 49.0 & 18.5 & 32.4 \\
\hline \hline
\end{tabular}

Source: Own calculations based on SHIW. 
Table 13a: Average gain (loss) by age groups (individual taxpayers) - "Stock-neutral reform"

\begin{tabular}{|c|c|c|c|c|c|c|c|c|c|c|c|c|}
\hline & \multicolumn{4}{|c|}{ SCENARIO 1} & \multicolumn{4}{|c|}{ SCENARIO 2} & \multicolumn{4}{|c|}{$\begin{array}{l}\text { SCENARIO } 3 \text { (10,000 euro) } \\
\end{array}$} \\
\hline & & Win & & Lose & & Win & & Lose & & Win & & Lose \\
\hline Age group & Euro & $\begin{array}{c}\text { \% of actual } \\
\text { PIT gross } \\
\text { income }\end{array}$ & Euro & $\begin{array}{l}\% \text { of actual PIT } \\
\text { gross income }\end{array}$ & Euro & $\begin{array}{l}\text { \% of actual } \\
\text { PIT gross } \\
\text { income }\end{array}$ & Euro & $\begin{array}{l}\% \text { of actual PIT } \\
\text { gross income }\end{array}$ & Euro & $\begin{array}{l}\text { \% of actual } \\
\text { PIT gross } \\
\text { income }\end{array}$ & Euro & $\begin{array}{l}\% \text { of actual PIT } \\
\text { gross income }\end{array}$ \\
\hline$\leq 35$ & 873 & 4.6 & 918 & 5.7 & 825 & 4.3 & 910 & 5.7 & 822 & 4.4 & 1074 & 4.7 \\
\hline$>35 \& \leq 65$ & 887 & 3.3 & 1123 & 5.4 & 972 & 3.4 & 1081 & 5.8 & 828 & 3.2 & 1268 & 5.0 \\
\hline$>65$ & 636 & 2.9 & 1068 & 6.1 & 721 & 3.0 & 1047 & 6.4 & 607 & 2.8 & 1128 & 5.9 \\
\hline Totale & 840 & 3.5 & 1090 & 5.7 & 890 & 3.5 & 1057 & 5.9 & 790 & 3.4 & 1206 & 5.2 \\
\hline
\end{tabular}

Source: Own calculations based on SHIW. 
Table 13b: Average gain (loss) by age groups (individual taxpayers) - "Bond-neutral reform"

\begin{tabular}{|c|c|c|c|c|c|c|c|c|c|c|c|c|}
\hline & \multicolumn{4}{|c|}{ SCENARIO 1} & \multicolumn{4}{|c|}{ SCENARIO 2} & \multicolumn{4}{|c|}{ SCENARIO 3 (10,000 euro) } \\
\hline & & Win & & Lose & & Win & & Lose & & Win & & Lose \\
\hline Age group & Euro & $\begin{array}{l}\text { \% of actual } \\
\text { PIT gross } \\
\text { income }\end{array}$ & Euro & $\begin{array}{l}\% \text { of actual PIT } \\
\text { gross income }\end{array}$ & Euro & $\begin{array}{l}\text { \% of actual } \\
\text { PIT gross } \\
\text { income }\end{array}$ & Euro & $\begin{array}{l}\text { \% of actual PIT } \\
\text { gross income }\end{array}$ & Euro & $\begin{array}{l}\text { \% of actual } \\
\text { PIT gross } \\
\text { income }\end{array}$ & Euro & $\begin{array}{l}\% \text { of actual PIT } \\
\text { gross income }\end{array}$ \\
\hline$\leq 35$ & 670 & 3.5 & 729 & 4.9 & 618 & 3.2 & 695 & 4.9 & 600 & 3.2 & 738 & 3.4 \\
\hline$>35 \& \leq 65$ & 639 & 2.3 & 775 & 4.3 & 738 & 2.5 & 765 & 4.9 & 551 & 2.2 & 837 & 3.4 \\
\hline$>65$ & 481 & 2.1 & 740 & 5.1 & 577 & 2.3 & 736 & 5.4 & 429 & 2.1 & 814 & 4.3 \\
\hline Totale & 620 & 2.6 & 759 & 4.6 & 679 & 2.6 & 750 & 5.1 & 543 & 2.4 & 822 & 3.6 \\
\hline
\end{tabular}

Source: Own calculations based on SHIW. 


\section{Concluding Remarks}

In this paper we study the distributive impact of current housing taxation in Italy, and then compare this with an alternative approach which considers a broader definition of income, that includes - in particular - a 'market' imputed rent from owner-occupied dwelling. This would allow to make the tax system neutral with respect to investments in housing as well as in alternative assets, like stocks and bonds. The analysis is based on a static microsimulation model that uses as input data those provided by the Bank of Italy in its Survey on Households Income and Wealth. We first simulate the distribution of the 2008 housing taxation on households. We then highlight the efficiency problems and the distributive consequences of this tax system with respect to one in which a 'market' imputed rent is included in the Personal Income Tax base.

Our results show that, by including the imputed rent from owner-occupied dwellings in the Personal Income Tax base, overall inequality - measured by the Gini coefficient - is reducing, while contemporaneously increasing efficiency in the allocation of wealth. Moreover, considering changes in tax liabilities, we show that taxing imputed rents will favour the young and penalise the elderly. Housing taxation is then shown to be a matter of intertemporal redistribution across generations, which should be considered when analysing the impact of other welfare benefits. 


\section{References}

Aaberge R., Colombino U. and Strøm S. (1999), Labour Supply in Italy: An Empirical Analysis of Joint Household Decisions, with Taxes and Quantity Constraints, Journal of Applied Econometrics, 14 (4), 403-422.

Aaron H. (1970), Income Taxes and Housing, American Economic Review, 60 (5), 789806.

Bank of Italy (2010), Household Income and Wealth in 2008, Supplements to the Statistical Bulletin, Vol. XX (New Series), n. 8.

Berloffa G. and Villa P. (2010), Differences in equivalent income across cohorts of households, Review of Income and Wealth, 56 (4), 693-714.

Bernardi F. and Poggio T. (2004), Home ownership and social inequality in Italy, in K. Kurz and Blossfeld H. P. (eds.), Home ownership and social inequality in comparative perspective, Stanford: Stanford University Press, 187-232.

Bourassa S. C. and Hendershott P. H. (1994), On the equity effects of taxing imputed rent: Evidence from Australia, Housing Policy Debate, 5 (1), 73-95.

Callan T. and Keane C. (2009), Non-Cash Benefits and the Distribution of Economic Welfare, IZA Discussion Paper, n. 3954.

Canberra Group (2001), Final Report and Recommendations, Expert Group on Household Income Statistics, Ottawa.

D’Alessio G. and Gambacorta R. (2007), L'accesso all'abitazione di residenza in Italia, Banca d'Italia, Quaderni di Economia e Finanza (Occasional Papers), n. 9.

D’Ambrosio C. and Gigliarano C. (2007), The distributional impact of "imputed rent" in Italy, Aim-Ap Project, ISER, University of Essex, mimeo.

Ferrera M. and Castles F. (1996), Home ownership and the Welfare State: is Southern Europe different?, South European Politics and Society, 1(2), 163-185.

Frick J. R. and Grabka M. M. (2003), Imputed Rent and Income Inequality: a Decomposition Analysis for Great Britain, West Germany and the U.S., Review of Income and Wealth, 49 (4), 513-537.

Frick J. R., Grabka M. M., Smeeding T. M. and Tsakloglou P. (2010), Distributional effects of imputed rents in five European countries, Journal of Housing Economics, 19, 167-179. 
Gale W. G., Gruber J., and Stephens-Davidowitz S. (2007), Encouraging Homeownership Through the Tax Code, Tax Notes, June 18, 1171-1189.

Garner T., Short K. (2009), Accounting for owner-occupied dwelling services: Aggregates and distribution, Journal of Housing Economics, 18, 233-248.

Glaeser, E. and B. Sacerdote (1999), Why is there more crime in cities?, Journal of Political Economy, 107, S225-S258.

Goode R. (1960), Imputed rent of owner-occupied dwellings under the income tax, Journal of Finance, 15(4), 504-530.

Green R. K. and White M. J. (1997), Measuring the benefits of home-owning: Effects on Children, Journal of Urban Economics, 41, 441-461.

Jappelli T. and Pistaferri L. (2007), Do people respond to tax incentives? An analysis of the Italian reform of the deductibility of home mortgage interests, European Economic Review, 51, 247-271.

Mirrlees J., S. Adam, T. Besley, R. Blundell, S. Bond, R. Chote, M. Gammie, P. Johnson, G. Myles and J. Poterba (eds) (2011), Tax by Design: the Mirrlees Review, Oxford University Press.

Onrubia J., Carmen Rodado M., Ayala L. (2009), How do services of owner-occupied housing affect income inequality and redistribution?, Journal of Housing Economics, 18, 224-232.

Pellegrino S., Piacenza M., Turati G. (2011), Developing a static microsimulation model for the analysis of housing taxation in Italy, International Journal of Microsimulation, 4(2), 73-85.

Pellegrino S. and Turati G. (2011), Reducing the tax wedge on labour income by reforming housing taxation: Can this reform achieve a political majority?, Giornale degli Economisti, 70(1), 123-154.

Poterba J. M. (1992), Taxation and housing: old questions, new answers, American Economic Review, 82 (2), 237-242.

Quigley J. M. (2008), Housing Policy in the United States, in S. Durlauf and L. E. Blume (eds.), The New Palgrave Dictionary of Economics, Palgrave MacMillan.

Reviglio F. (1998), Come siamo entrati in Europa e perché potremmo uscirne, Utet.

Rosen H. (1985), Housing Subsidies. Effects on Housing Decisions, Efficiency, and Equity, in Auerbach A. J. and Feldstein M. (eds.), Handbook of Public Economics, Elsevier (North-Holland), vol. I, 375-420. 
Sierminska E., A. Brandolini and T. M. Smeeding (2008), Comparing Wealth Distribution Across Rich Countries: First Results From the Luxembourg Wealth Study, in Household wealth in Italy, Rome: Bank of Italy.

Thalmann P. (2007), Tenure-neutral and equitable housing taxation, Urban Studies, 44(2), 275-296.

Shorrocks A., Davies J. and Lluberas R. (2010), Global Wealth Report, Research Institute, Credit Suisse.

Watson D., R. Webb, T. Hinks and M. Brooks (2007), European Castles? The Wellbeing Effects of Home Ownership and Housing Market Disparities in the European Union, University of Wales, mimeo.

Wolff E. N. and Zacharias A. (2009), Household Wealth and the Measurement of Economic Well-Being in the United States, Journal of Economic Inequality, 7(2), 83-115.

Yagi T. and Tachinabaki T. (1998), Income Redistribution Through the Tax System: A Simulation Analysis of Tax Reform, Review of Income and Wealth, 44 (3), 397-415.

Yates J. (1994), Imputed Rent and Income Distribution, Review of Income and Wealth, 40 (1), 43-66. 